УДК 577.11

\title{
The New Strain of Acetic Acid Bacteria \\ Komagataeibacter xylinus B-12068 - \\ Producer of Bacterial Cellulose \\ for Biomedical Applications
}

\author{
Svetlana V. Prudnikova* and Ivan P. Shidlovsky \\ Siberian Federal University \\ 79 Svobodny, Krasnoyarsk, 660041, Russia
}

Received 28.08.2016, received in revised form 05.10.2016, accepted 19.10.2016

The strain of acetic acid bacteria Komagataeibacter xylinus B-12068, producing of bacterial cellulose $(B C)$, was isolated and described. The effects of cultivation conditions (carbon sources, temperature, and $\mathrm{pH}$ ) on $B C$ production and properties were studied in surface and submerged cultures. Glucose was found to be the best substrate for BC production among the sugars tested; ethanol concentration of $3 \%(w / v)$ enhanced the productivity of BC. The highest BC yield (up to $17.0 \mathrm{~g} / \mathrm{L}$ ) was obtained under surface static cultivation conditions, in the modified HS medium supplemented with ethanol, at pH 3.9, after 7 days of cultivation in the thinnest layer of the medium.

Keywords: Komagataeibacter xylinus, acetic acid bacteria, bacterial cellulose production.

Citation: Prudnikova S.V., Shidlovsky I.P. The new strain of acetic acid bacteria Komagataeibacter xylinus B-12068 - producer of bacterial cellulose for biomedical applications. J. Sib. Fed. Univ. Biol., 2017, 10(2), 246-254. DOI: 10.17516/1997-13890017 .

(C) Siberian Federal University. All rights reserved

* Corresponding author E-mail address: sveet_s@bk.ru 


\section{Новый штамм уксуснокислых бактерий}

Komagataeibacter xylinus B-12068 -

продуцент бактериальной целлюлозы

для биомедицинского применения

С.В. Прудникова, И.П. Шидловский

Сибирский федеральный университет

Россия, 660041, Красноярск, пр. Свободный, 79

Выделен и описан штамм уксуснокислых бактерий Komagataeibacter xylinus B-12068, продуцент бактериальной целлюлозы (БЦ). Изучено влияние условий выращивания штамма (источники углерода, температура и рН) в поверхностном и глубинном режимах на выход и свойства БЦ. Показано, что из спектра сахаров глюкоза является лучшим субстратом для получения БЦ; этанол в концентрации 3 \% (w/v) стимулирует синтез БЦ. Максимальная продукция БЦ (до 17.0 г/л) получена при поверхностном статическом культивировании штамма в течение 7 сут при рН 3.9 на модифицированной среде HS с добавками этанола при минимальном слое среды.

Ключевые слова: Котаgataeibacter хуlinus, уксуснокислье бактерии, получение бактериальной целлюлозы.

\section{Introduction}

Cellulose is extracellular polysaccharide synthesized by higher plants, lower phototrophs, and prokaryotes belonging to various taxa: Gluconacetobacter, Acetobacter, Komagataeibacter (Tanaka et al., 2000; Yamada et al., 2012). Except for bacteria and tunicates, cellulose is a component of the cell wall of plants, algae, and slime molds (Dictyostelium) (Saxena, Brown, 2005). Cellulose is used in a variety of applications in food and paper industries, medicine, and pharmaceutics. The chemical structure of bacterial cellulose (BC) is similar to that of plant-derived cellulose, but it has unique physical, mechanical, and chemical properties such as high strength, elasticity, gas permeability, high water-holding capacity, porosity, etc. Gel pellicles of $\mathrm{BC}$ have an ordered structure: they are 3D networks consisting of ribbon-like randomly oriented cellulose microfibrils. This structural arrangement of $\mathrm{BC}$ and its high compatibility with biological tissue make it attractive material for reconstructive surgery; skin tissue repair; target tissue regeneration in dentistry, general surgery, and maxillofacial surgery; and cell and tissue engineering - as carrier for drugs (Ma et al., 2010; Saska et al., 2011).

To increase the scale of production of bacterial cellulose and to widen the range of its applications, it is necessary to have bacterial strains capable of synthesizing high yields of this valuable product of biotechnology. Therefore, much of recent research has been focused on finding new cellulose-producing strains and improving the fermentation techniques.

The purpose of the present study was to investigate the strain Komagataeibacter xylinus B-12068 as a new producer of bacterial cellulose and evaluate the influence of culture conditions on the efficiency of bacterial cellulose production. 


\section{Materials and methods}

A new bacterial strain Komagataeibacter xylinus B-12068 was isolated from the fermented tea (kombucha) Medusomyces gisevii J. Lindau on Hestrin-Schramm (HS) medium (Hestrin, Schramm, 1954). The strain was identified based on its morphological, biochemical, genetic, and growth parameters. The morphology of bacterial cells was studied in Gram-stained preparations. The phenotypic properties were studied using conventional microbiological techniques. Growth on carbon sources such as glucose, sucrose, maltose, galactose and mannitol was tested in the basal HS-medium supplemented with $2 \%(\mathrm{w} / \mathrm{v})$ of each carbohydrate. To differentiate the strain from closely related species of Komagataeibacter requirement of acetic acid, growth in the presence of $30 \%(\mathrm{w} / \mathrm{v})$ D-glucose and growth on AE-medium were identified (Boone et al., 2005; Dellaglio et al., 2005).

Comparison of the 16S rRNA gene sequence of the strain with the sequences in the GenBank, EMBL, and DDBJ databases was performed using the NCBI BLAST software package (http://www.ncbi.nlm.nih.gov/BLAST/). For phylogenetic analysis, the nucleotide sequences were aligned with homologous referential sequences from the database NCBI RefSeq using the Muscle package of MEGA software version 6. Phylogenetic analysis was carried out according to the 3-parameter model Tamura, using the neighbor-joining method in the MEGA version 6 software package (Tamura et al., 2013).

To investigate the influence of the culture conditions on $\mathrm{BC}$ biosynthesis and to find the conditions maximizing cellulose yield, the standard medium was modified by replacing glucose by other carbon sources (maltose, mannitol, sucrose or galactose), varying initial $\mathrm{pH}$ values (3.2-4.8) by adding acetate or citrate, varying the temperature of the medium $\left(20-37{ }^{\circ} \mathrm{C}\right)$, and adding various concentrations of ethanol $(0.5-3.0 \%)$ to the medium, based on the data indicating that ethanol oxidized to acetate was a growth substrate and energy source for K. xylinus (Yamada et al., 2012). BC production by the strain was investigated under different culture conditions. Static cultivation was performed in the surface mode in Petri dishes, $1500-\mathrm{ml}$ glass trays, or $250-$ to $500-\mathrm{ml}$ glass flasks, which contained different volumes of the medium. Submerged cultivation was conducted in 500-ml glass flasks in a JEIO TECH SL-600 incubated shaker (JEIO TECH, Korea) at $100 \mathrm{rpm}$. Glucose concentration was determined using the "Glucose - FKD" kit, which contained chromogenic enzyme substrate and a calibrator (a glucose solution of a known concentration). Optical densities of the study sample and calibration sample were compared photometrically with the optical density of the blank, with optical path length $10 \mathrm{~mm}$ at wavelength $490 \mathrm{~nm}$.

$\mathrm{BC}$ yields in different modes of cultivation were compared by measuring the weight of the cellulose dried to constant weight, the pellicle thickness, and the amount of carbon substrate consumed. The total BC yield $(\mathrm{g} / \mathrm{L})$ and biosynthesis productivity for different fermentation processes were calculated using conventional methods. The $\mathrm{BC}$ yield was evaluated as the weight of dry cellulose per liter of medium $(\mathrm{g} / \mathrm{L})$. To measure it, $\mathrm{BC}$ samples were dried at $45{ }^{\circ} \mathrm{C}$ for 3 days until constant weight was obtained. The dried $\mathrm{BC}$ pellicles were weighed on the Adventurer OH-AR2140 analytical balance (Ohaus, Switzerland).

Statistical analysis of the results was performed by conventional methods, using the standard software package of Microsoft Excel. Arithmetic means and standard deviations were found. 


\section{Results and discussion}

The strain Komagataeibacter xylinus was deposited in the Russian National Collection of Industrial Microorganisms (VKPM) with registration number VKPM B-12068. The strain produced bacterial cellulose $(\mathrm{BC})$ in surface and submerged cultures (Prudnikova et al., 2014). Acetic acid bacteria of the genus Komagataeibacter, which were formerly known as Gluconacetobacter (Yamada et al., 2012), are currently studied as effective BC producers. The strain of Komagataeibacter xylinus B-12068 was identified based on morphological, physiological, molecular and genetic evidence as a new strain of the genus Komagataeibacter. The strain shows typical generic features. The colonies on solid HS medium are small, convex, opaque, pale and nonpigmented. Bacterial cells are Gram-negative, rod shaped, non-motile, and single or pair, 0.4-0.6 $\times 1.0-1.5 \mu \mathrm{m}$. The bacteria are strictly aerobic, positive in catalase and negative in oxidase tests, lack of proteolytic and amylolytic activity, require growth factors (yeast extract), sensitive to $\mathrm{NaCl}$ concentrations above $0.5 \%$. In the fatty acid composition palmitic, stearic and cis-vaccenic acids are dominant.

The optimal values of $\mathrm{pH}$ are 3.5-4.5; the temperature range to the maximum growth is
$28-30{ }^{\circ} \mathrm{C}$. The strain is resistant to majority of fluoroquinolones and cephalosporins, and shows various sensitivity to aminoglycosides, penicillins, and carbapenems. The strain uses glucose, sucrose, fructose, maltose as carbon sources and does not form bacterial cellulose on HS medium with galactose and mannitol.

The sequence of the DNA fragment encoding 16S rRNA, registered in the GenBank NCBI database under KJ000081 number, was determined to identify the strain. The analysis showed close similarity to several Komagataeibacter species, which reached 99$100 \%$ (Fig.). Published data also point to the close relationship of these species (Boone et al., 2005; Dellaglio et al., 2005).

The differentiating features of the strain K. xylinus B-12068 were used in conjunction with the genetic analysis to determine the species (Table 1). The strain K. xylinus B-12068 does not require of acetic acid for growth. No growth observed in the presence of $30 \% \mathrm{D}$-glucose and on $\mathrm{AE}$ medium in the presence of $3 \%$ ethanol and $6 \%$ acetic acid.

Different strains of acetic acid bacteria are able to synthesize bacterial cellulose (BC) from various carbon sources, including wastes, and the cellulose yield varies considerably,

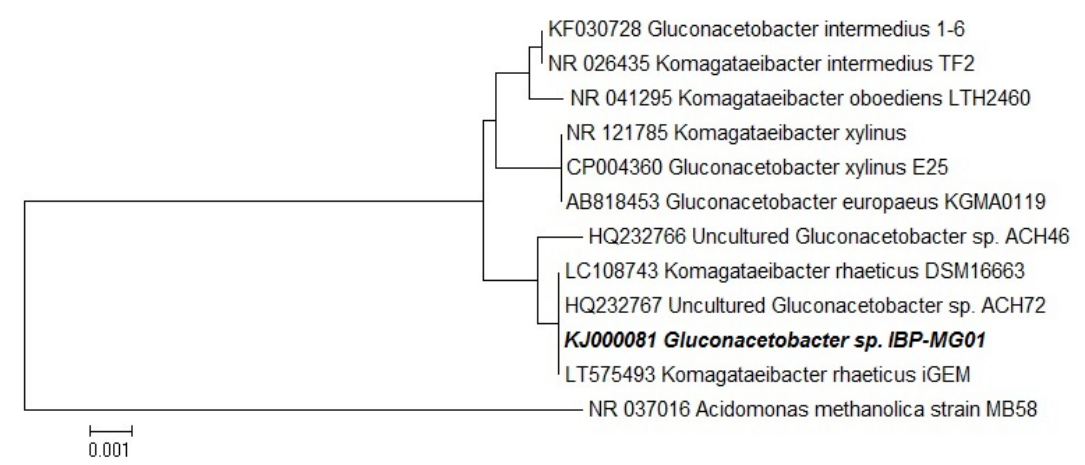

Fig. Phylogenetic position of the Komagataeibacter xylinus B-12068 (registered in the GenBank NCBI database as KJ000081 Gluconacetobacter sp. IBP-MG01) within the acetic acid bacteria based on the comparison of 1444 16S rRNA gene sequences using the neighbor-joining method. Scale bar, one nucleotide substitution for each thousand sequences 
Table 1. Differentiating markers of the strain Komagataeibacter xylinus B-12068

\begin{tabular}{|c|c|c|c|c|c|}
\hline Characteristics & $\begin{array}{c}\text { K. xylinus } \\
\text { B-12068 }\end{array}$ & K. intermedius & K. europaeus & K. rhaeticus & K. oboediens \\
\hline Cellulose formation & + & + & + & + & - \\
\hline $\begin{array}{l}\text { Requirement of acetic acid for } \\
\text { growth }\end{array}$ & - & - & + & - & - \\
\hline $\begin{array}{l}\text { Growth on } 3 \%(\mathrm{v} / \mathrm{v}) \text { ethanol in } \\
\text { the presence } 5-8 \% \text { acetic acid }\end{array}$ & - & + & + & + & + \\
\hline $\begin{array}{l}\text { Growth in the presence of } 30 \% \\
(w / v) \text { D-glucose }\end{array}$ & - & + & - & + & + \\
\hline
\end{tabular}

between $0.1-0.2$ and $2-6 \mathrm{~g} / \mathrm{L}$ (Park et al., 2003; Mohammadkazemi et al., 2015).

The highest BC yield (about $2.2 \mathrm{~g} / \mathrm{L}$ ) was obtained in the experiment with the K. xylinus B-12068 cells cultivated for 7 days in the HS medium containing glucose. The $\mathrm{BC}$ yield in the media with sucrose and galactose was somewhat lower -1.6 and $1.4 \mathrm{~g} / \mathrm{L}$, respectively. On the media containing maltose and mannitol, $\mathrm{BC}$ production was very low, about $0.1-0.2 \mathrm{~g} / \mathrm{L}$, i.e. these carbon sources were not suitable for production of bacterial cellulose by this strain. The physiological glucose range for this strain is rather wide; K. xylinus B-12068 growth and $\mathrm{BC}$ production were inhibited at glucose concentration in the culture medium higher than $25 \%(\mathrm{w} / \mathrm{v})$. Mohammadkazemi et al. (2015) reported a study of the effects of carbon sources and nitrogen concentration in the culture medium on BC production. Castro et al. (2012) also showed the effect of the carbon source on $\mathrm{BC}$ production: the $\mathrm{BC}$ yield from glucose was the highest $(3 \mathrm{~g} / \mathrm{L})$ while the medium containing sucrose yielded $2 \mathrm{~g} / \mathrm{L}$, and the media with fructose and mannitol - no more than $0.4 \mathrm{~g} / \mathrm{L}$. These data are consistent with the results reported in another study, which showed that such carbon sources as maltose, cellobiose, xylose, and galactose were less suitable for BC production by Acetobacter xylinum than glucose (Surma-Ślusarska et al., 2008).
As $\mathrm{BC}$ production is influenced not only by carbon sources but also by agitation conditions, the medium volume to surface area ratio, $\mathrm{pH}$ of the medium, and addition of the secondary carbon substrates to the medium (Pokalwar et al., 2010; Ruka et al., 2012; Fu et al., 2013; Keshk, 2014; Li et al., 2015), we investigated cellulose production under varied conditions of K. xylinus B-12068 cultivation. The initial pH value influenced cellulose production by the strain. The physiological $\mathrm{pH}$ range for $K$. xylinus B-12068 is between 3.2 and 5.0, while the optimal $\mathrm{pH}$ range for $\mathrm{BC}$ biosynthesis is very narrow between 3.6 and 4.0. The highest BC yield from the standard HS medium $(2.73 \mathrm{~g} / \mathrm{L})$ was obtained at $\mathrm{pH}$ 3.6. When K. xylinus B-12068 cells were cultivated in the glucose-enriched medium, the initial $\mathrm{pH}$ value of 6.0 dropped to 3.4 after 7 days of cultivation due to accumulation of products of glucose oxidation, mainly, gluconic acid. As K. xylinus B-12068 was found to be acid tolerant, the $\mathrm{pH}$ of the medium, which decreased during cultivation, did not need to be adjusted. During cultivation of $K$. xylinus B-12068 in the media containing such poorly utilized carbon sources as maltose and mannitol, $\mathrm{pH}$ did not decrease considerably - only to 5.45.8. Different strains of acetic acid bacteria show varying acid tolerance. In a study by Castro et al. (2012), the highest BC yields were obtained in G. medellensis culture at pH 3.5 (up 
to $4.5 \mathrm{~g} / \mathrm{L}$ ). The ability of bacteria to synthesize $\mathrm{BC}$ at low $\mathrm{pH}$ values can be used to reduce the risk of contamination of the commercial strain by foreign microflora.

The effect of the temperature of the K. xylinus B-12068 culture medium on BC production suggesting that the optimal temperature range for cell growth and $\mathrm{BC}$ production is rather narrow 28-30 ${ }^{\circ} \mathrm{C}$, while the physiological temperature range is wide $\left(20-37^{\circ} \mathrm{C}\right)$.

Based on the data suggesting that acetic acid bacteria are capable of oxidizing ethanol and that in some cases, ethanol enhances the productivity of BC, e.g. in G. hansenii culture (Park et al., 2003), we investigated the effect of ethanol as a secondary substrate on $\mathrm{BC}$ production by K. xylinus B-12068 cultivated in the HS medium enriched with glucose. The increase in ethanol concentration from 0.5 to $3.0 \%$ (v/v) resulted in an increase in cellulose production, from 1.38 to $3.06 \mathrm{~g} / \mathrm{L}$. The highest $\mathrm{BC}$ yields were obtained at ethanol concentration of $3 \%$.

As glucose was determined as the best substrate for K. xylinus B-12068, it was used as carbon substrate in the subsequent experiments. Results of the comparative study of the effects of cultivation conditions on $\mathrm{BC}$ production are given in Table 2.
When the strain was grown on the surface of glucose-enriched HS medium $(100 \mathrm{ml}$, the layer of the medium $2.0 \pm 0.1 \mathrm{~cm}$ high) under static conditions, the $\mathrm{BC}$ productivity and the effectiveness of substrate (glucose) consumption were the lowest. Under agitated conditions, BC yield was 1.6 times higher than under static ones, reaching $2.8 \mathrm{~g} / \mathrm{L}$. Under agitated conditions, however, in contrast to the static culture, cellulose did not form a pellicle at the air/culture medium interface but was shaped as spheres, filaments, and fibers distributed over the volume of the culture medium.

Modification of HS medium by adding ethanol concentration of $3 \%(\mathrm{v} / \mathrm{v})$ and decreasing the initial $\mathrm{pH}$ value to 3.9 enhanced $\mathrm{BC}$ productivity of $K$. xylinus B-12068 to $6.8-7.9 \mathrm{~g} / \mathrm{L}$ under static conditions and to $6.2 \mathrm{~g} / \mathrm{L}$ under shaking. The efficiency of $\mathrm{BC}$ production on modified medium varied within a narrow range between 37.1 до $39.8 \%$ glucose. The use of citrate or acetate to achieve the initial value of $\mathrm{pH}$ of the medium did not cause any significant changes in $\mathrm{BC}$ production (Table 1).

The available data on the effect of culture conditions (static or agitated culture) are contradictory. Some data suggested (Schramm, Hestrin, 1954) that cellulose did not form

Table 2. Bacterial cellulose production on standard and modified Hestrin-Schramm media in different volumes

\begin{tabular}{|c|c|c|}
\hline $\begin{array}{l}\text { Culture conditions } \\
\text { Carbon source, medium, volume }\end{array}$ & $\mathrm{BC}(\mathrm{g} / \mathrm{l})$ & $\begin{array}{c}\text { Yield } \\
\text { coefficient ( \%) }\end{array}$ \\
\hline \multicolumn{3}{|c|}{ Static conditions } \\
\hline Flask, HS standard medium (glucose), $100 \mathrm{ml}$ & 1.7 & 8.3 \\
\hline Flask, HS modified medium (glucose+ethanol), $100 \mathrm{ml}$ & 7.9 & 39.3 \\
\hline Petri dishes, HS standard medium (glucose), $25 \mathrm{ml}$ & 4.3 & 21.4 \\
\hline Petri dishes, HS modified medium (glucose+ethanol), $25 \mathrm{ml}$ & 17.0 & 85.0 \\
\hline Glass tray, HS modified medium (glucose+ethanol), $500 \mathrm{ml}$ & 6.8 & 39.8 \\
\hline \multicolumn{3}{|c|}{ Agitated conditions } \\
\hline Flask, standard medium (glucose), $150 \mathrm{ml}$ & 2.8 & 16.9 \\
\hline Flask, modified medium (glucose+ethanol), $150 \mathrm{ml}$ & 6.2 & 37.1 \\
\hline
\end{tabular}


pellicles in the agitated media with G. xylinus culture but accumulated as irregular spherical pellets in the medium; cellulose yield was found to decrease. Ruka et al. (2012), however, showed that when G. xylinus was grown under static and agitated conditions in the highproduction Yamanaka-mannitol, Zhou-sucrose, and Zhou-mannitol media, no difference was observed between BC yields. Ruka et al. (2012) varied the sizes of fermentation vessels and the volumes of the media in them and found that the highest cellulose production was obtained in the bioreactor with the largest surface area. The use of greater volumes of the medium resulted in higher cellulose yields, but that also increased production cost and time. Moreover, the layer of the medium had to be sufficiently thick for cellulose to be completely immersed in it during the production process. Authors of another study (Pa'e et al., 2011) compared BC yields in the static culture of A. xylinum and in the agitated culture by using a Rotary Discs Reactor, RDR, and found an $80.77 \%$ difference, with the $\mathrm{BC}$ production being considerably higher in the bioreactor than in the static culture.

In the present study, the highest BC yield (about $17.0 \mathrm{~g} / \mathrm{L}$ ) was observed in the experiment with K. xylinus B-12068 grown in Petri dishes containing $20 \mathrm{ml}$ of the medium (the medium layer being $0.5 \pm 0.1 \mathrm{~cm}$ thick). In Petri dishes, the volume of the medium was four times smaller than in the flasks but the surface area was the same as in the flasks $\left(60 \pm 1 \mathrm{~cm}^{2}\right)$, and the amount of the substrate (glucose) was 2.2-2.6 times smaller (Table 1). These results are in good agreement with the data in the study by Ruka et al. (2012), showing that the lower volume of the nutrient medium in the vessel did not decrease $\mathrm{BC}$ production but increased the efficiency of utilization of carbon substrate.

Thus, in the present study, high yields of $\mathrm{BC}$ were obtained from the culture of $K$. xylinus B-12068 - a new strain of acetic acid bacteria. The highest $\mathrm{BC}$ yields reported in the literature were 1.2-4.5 g/L (Castro et al., 2012; Ruka et al., 2012) and $5.96 \mathrm{~g} / \mathrm{L}$ - from the culture of a mutant strain (Hungund, Gupta, 2010).

\section{Conclusion}

In the present study, we investigated production of bacterial cellulose in the culture of the strain Komagataeibacter xylinus B-12068 from different carbon sources and under different culture conditions. The highest BC yield (7.9-17.0 g/L) was obtained in the modified glucose-enriched HS medium supplemented with ethanol at $30^{\circ} \mathrm{C}$ and $\mathrm{pH} 3.9$ over 7 days of cultivation.

\section{Acknowledgement}

The reported study was funded by RFBR and Government of Krasnoyarsk Territory according to the research project № 16-43-242024 and by the State budget allocated to the fundamental research at the Russian Academy of Sciences (№ AAAA-A17- 117013050028-8).

\section{References}

Boone D.R., Castenholz R.W., Garrity G.M., Brenner D.J., Krieg N.R., Staley J.T. (eds.) (2005) Bergey's Manual ${ }^{\circledR}$ of Systematic Bacteriology (Vol. 2). Springer Science \& Business Media

Castro C., Zuluaga R., Álvarez C., Putaux J.L., Caro G., Rojas O.J., Mondragon I., Gañán P. (2012) Bacterial cellulose produced by a new acid-resistant strain of Gluconacetobacter genus. Carbohydrate Polymers, 89(4): 1033-1037

Dellaglio F., Cleenwerck I., Felis G.E., Engelbeen K., Janssens D., Marzotto M. (2005) Description of Gluconacetobacter swingsii sp. nov. and Gluconacetobacter rhaeticus sp. nov., 
isolated from Italian apple fruit. International Journal of Systematic and Evolutionary Microbiology, 55(6): 2365-2370

Fu L., Zhang J., Yang G. (2013) Present status and applications of bacterial cellulose-based materials for skin tissue repair. Carbohydrate Polymers, 92(2): 1432-1442

Hestrin S., Schramm M. (1954) Synthesis of cellulose by Acetobacter xylinum. 2. Preparation of freeze-dried cells capable of polymerizing glucose to cellulose. Biochemical Journal, 58(2): 345

Hungund B.S., Gupta S.G. (2010) Strain improvement of Gluconacetobacter xylinus NCIM 2526 for bacterial cellulose production. African Journal of Biotechnology, 9(32): 5170-5172

Keshk S.M.A.S. (2014) Bacterial cellulose production and its industrial applications. Journal of Bioprocessing \& Biotechniques, 4(2): 150

Li Z., Wang L., Hua J., Jia S., Zhang J., Liu H. (2015) Production of nano bacterial cellulose from waste water of candied jujube-processing industry using Acetobacter xylinum. Carbohydrate Polymers, 120: 115-119

Ma X., Wang R.M., Guan F.M., Wang T.F. (2010) Artificial dura mater made from bacterial cellulose and polyvinyl alcohol. CN Patent ZL200710015537, 5

Mohammadkazemi F., Azin M., Ashori A. (2015) Production of bacterial cellulose using different carbon sources and culture media. Carbohydrate Polymers, 117: 518-523

Pa'e N., Zahan K.A., Muhamad I.I. (2011) Production of biopolymer from Acetobacter xylinum using different fermentation methods. International Journal of Engineering and Technology, 11(5): 90-98

Park J.K., Jung J.Y., Park Y.H. (2003) Cellulose production by Gluconacetobacter hansenii in a medium containing ethanol. Biotechnology Letters, 25(24): 2055-2059

Pokalwar S.U., Mishra M.K., Manwar A.V. (2010) Production of cellulose by Gluconacetobacter sp. Recent Research in Science and Technology, 2(7): 14-19

Prudnikova S.V., Volova T.G., Shishatskaya E.I. (2014) Shtamm bakterii Komagataeibacter xylinus - produtsent bakterialnoi tsellulozy (A strain of bacterium Komagataeibacter xylinus - a producer of bacterial cellulose). RF Patent for an invention No. 2568605. Priority of 11 December 2014. Registered in the RF State Register on 27 October 2015 (in Russian)

Ruka D.R., Simon G.P., Dean K.M. (2012) Altering the growth conditions of Gluconacetobacter xylinus to maximize the yield of bacterial cellulose. Carbohydrate Polymers, 89(2): 613-622

Saska S., Barud H.S., Gaspar A.M.M., Marchetto R., Ribeiro S.J.L., Messaddeq Y. (2011) Bacterial cellulose-hydroxyapatite nanocomposites for bone regeneration. International Journal of Biomaterials, 2011: Article ID 175362, 8 p.

Saxena I.M., Brown R.M. (2005) Cellulose biosynthesis: current views and evolving concepts. Annals of Botany, 96(1): 9-21

Schramm M., Hestrin S. (1954) Factors affecting production of cellulose at the air/liquid interface of a culture of Acetobacter xylinum. Microbiology, 11(1): 123-129

Surma-Ślusarska B., Presler S., Danielewicz D. (2008) Characteristics of bacterial cellulose obtained from Acetobacter xylinum culture for application in papermaking. Fibres \& Textiles in Eastern Europe, 4(69): 108-111

Tanaka M., Murakami S., Shinke R., Aoki K. (2000) Genetic characteristics of cellulose-forming acetic acid bacteria identified phenotypically as Gluconacetobacter xylinus. Bioscience, Biotechnology, and Biochemistry, 64(4): 757-760 
Tamura K., Stecher G., Peterson D., Filipski A., Kumar S. (2013) MEGA6: molecular evolutionary genetics analysis version 6.0. Molecular Biology and Evolution, 30(12): 2725-2729

Yamada Y., Yukphan P., Lan Vu H.T., Muramatsu Y., Ochaikul D., Tanasupawat S., Nakagawa Y. (2012) Description of Komagataeibacter gen. nov., with proposals of new combinations (Acetobacteraceae). The Journal of General and Applied Microbiology, 58(5): 397-404 